\section{VAN DE REDACTIE}

De heer $\operatorname{Drs}_{\text {rs }} M$. Behrens heeft zich wegens verandering van werkkring en vertrek naar elders genoodzaakt gezien om zijn mandaat als redacteur van het Repertorium ter beschikking van de Redactie te stellen. Wij zeggen den heer Behrens dank voor de zorgen, door hem aan het Repertorium besteed.

Tot ons genoegen hebben wij den heer Drs P.F.R. Stol bereid gevonden om de werkzaamheden van den heer Behtens voor het Repertorium voort te zetten.

Geruimen tijd heeft de rubriek examen-vraagstukken gesluimerd. Deze rubriek, die bestemd is voor opneming van uitgewerkte examen-vraagstukken heeft gedurende vele jaren waardevolle bijdragen gebracht van de hand van hare redacteuren, de heeren Drs Abr. Meij en Drs J. Paardekooper. Tot ons leedwezen hebben deze heeren wegens drukke bezigheden hun arbeid aan de genoemde rubriek moeten staken. Wij spreken gaarne onze groote waardeering uit voor de wijze, waarop de afgetreden redacteuren zich van hun taak hebben gekweten; zij hebben met hun arbeid talrijke studeerenden aan zich verplicht.

Overtuigd als wij zijn van het nut, dat deze rubriek nog steeds voor studeerenden heeft, hebben wij ons beijverd om in de ontstane vacaturen te voorzien. Wij prijzen ons gelukkig Mevrouw $M, G$. Meij-Koning en den heer P. W. Th. Gerbers bereid te hebben gevonden hun krachten aan de genoemde rubriek te wijden. Een eerste bijdrage van de nieuwe rubriek-redactie treffen de lezers in deze aflevering aan.

\section{EENIGE OPMERKINGEN OVER DE ONDER- ZOEKEN DOOR RIJKSACCOUNTANTS TEN BEHOEVE VAN DE BELASTINGADMINISTRATIE}

De overwegingen van een arrest van den Hoogen Raad van 23 November 1938, opgenomen in Deel XII Afl. 7 van Beslissingen in Belastingzaken (No. 6782), handelende over de vragen:

$1^{\circ}$. ,of het enkele feit, dat vóór het opleggen van een oorspronkelijken aanslag een accountantsonderzoek heeft plaats gehad, medebrengt, dat niet hetzij door een nader accountantsonderzoek, hetzij op andere wijze, nieuwe feiten - die grond voor navordering opleveren - aan den dag kunnen treden";

$2^{\circ}$. „of bij een boekonderzoek de inspecteur of de accountant zich onder alle omstandigheden moet begeven in een nasporen en waardeeren van alle gegevens, die uit de boekhouding of wel aan de hand daarvan uit andere omstandigheden, kunnen worden getrokken";

komen mij voor van genoegzaam belang te zijn om aan de lezers van dit blad te worden voorgelegd.

\section{De feiten meen ik als volgt te mogen weergeven.}

De Heer A. was na accountantsonderzoek aangeslagen voor het belastingjaar 1934/35 naar een inkomen van $f$ 2500.- . Vóór het verstrijken van den navorderingstermijn wordt hem een naderen aanslag naar een inkomen van $f$ 6500.- opgelegd, omdat uit een na het opleggen van den primitieven aan- slag ten behoeve van de omzetbelastingwet door den Rijksaccoutant ingesteld onderzoek was gebleken, dat A. zeer hooge prijzen aan zijn uitbrengklanten in rekening bracht en uit een berekening gebaseerd op deze verkoopprijzen, waarbij rekening was gehouden met lagere prijzen bij winkelverkoop, was gebleken, dat de omzet belangrijk hooger moest zijn geweest, dan uit de boekhouding bleek. Daaruit werd geconcludeerd, dat de ontvangsten te laag waren opgegeven en de winst te laag was berekend.

Voor den Raad van Beroep stelde A., voorzoover hier ter zake dienende, als bezwaar, dat geen nieuw feit in den zin der wet aanwezig was, dat immers balans en verlies - en winstrekening bij de aangifte waren overgelegd, dat de navordering, niet gegrond is op de onjuistheid dezer cijfers, maar op een andere berekening van de winst t.w. naar een bepaald percentage van den omzet, welke berekening de inspecteur en ook de accountant (bij het eerste onderzoek) ook vóór het opleggen van den aanslag had kunnen en behooren te maken.

De Raad van Beroep wees dit verweer af en overwoog te dezen aanzien, dat bij het eerste onderzoek ,alleen de boekhouding is gecontroleerd, waarbij geen reden is gevonden, daarvan af te wijken, daar er geen onjuistheden in gevonden waren, en het bruto-winstpercentage als normaal was te beschouwen". Eerst bij de tweede contrôle voor de omzetbelasting was van hooge verkoopprijzen gebleken. Dit feit leverde grond op voor het vermoeden, dat de ontvangsten te laag waren opgegeven en was een nieuw feit, waarop de navorderingsaanslag kon worden gegrond.

Belanghebbende kon zich met de uitspraak van den Raad van Beroep niet vereenigen en kwam bij den Hoogen Raad in beroep. Deze overwoog:

,dat belanghebbendes meening, dat de Inspecteur bij het opleggen van een primitieven aanslag reeds bekend had behooren te zijn met netgeen hij aanvoert tot motiveering van den navorderingsaanslag, er op steunt, dat vóór het opleggen van den primitieven aanslag een accountantsonderzoek had plaats gevonden;

dat die gevolgtrekking echter niet juist is;

dat toch het enkele feit, dat een accountantsonderzoek heeft plaatsgevonden, geenszins medebrengt, dat niet, hetzij door een nader accountantsonderzoek, hetzij op andere wijze, nieuwe feiten aan den dag kunnen treden;

dat ...... ten onrechte in het middel de eisch is gesteld, dat die prijzen reeds bij het eerste onderzoek onder cle aandacht van den accountant hadden moeten komen; dat toch die eisch er geen rekening mede houdt dat, zoomin als dat van den inspecteur, indien deze zelf een boekonderzoek verricht, gevorderd kan worden, ook een accountant zich niet onder alle omstandigheden behoeft te begeven in een nasporen en waardeeren van alle gegevens, die uit de boekhouding of wel aan de hand daarvan uit andere omstandigheden, kunnen worden getrokken."

Naar mijn gevoelen geeft deze uitspraak blijk van een onjuiste opvatting omtrent functie, taak en verantwoordelijkheid van den accountant.

Allereerst reeds in de eerste overweging:

al heeft reeds een accountantsonderzoek plaats gevonden, dan kunnen toch bij een tweede accountantsonderzoek nieuwe feiten aan den dag treden. Ik acht deze stelling onhoudbaar. Wanneer een accountant de juistheid van een belastingaangifte heeft te controleeren en daarover heeft te rapporteeren, dan moet hij zijn werkzaamheden op zoodanige wijze verrichten, dat hij op goede gronden overtuigd kan zijn van de juistheid van de door hem medegedeelde uitkomst. Dan is er geen plaats voor een tweede onderzoek, waarbij nadere feiten blijken, die de eerste accountant niet heeft opgemerkt. 
Gebeurt dit wel, dan heeft het onderzoek van dezen niet aan alle daaraan te stellen eischen voldaan.

De eerste accountant heeft, ,alleen de boekhouding gecontroleerd" zegt de Raad van Beroep. Dit is verwonderlijk in meer dan één opzicht. Thans wil ik hieromtrent alleen dit op merken:

Uit andere overwegingen van het arrest blijkt, dat de boekhouding volgens de enkelvoudige methode werd gevoerd en belanghebbende niet voldoende vakbekwaam was en uit dien hoofde de winstberekening van den tweeden accountant op grond van verkoopcijfers de voorkeur verdiende boven het volgen van de boekhouding, welke gebreken vertoonde. Afgezien van de vraag, wat in dit geval werd verstaan onder ",de boekhouding gecontroleerd", komt net mij voor, dat de accountant, belast met het eerste onderzoek, gezien de genoemde onvolmaaktheden, zeer zeker zijn taak ruimer had behooren op te vatten dan hij blijkbaar heeft gedaan.

In de tweede plaats wil ik waarschuwen tegen de opvatting, blijkende uit de laatstgenoemde overweging van den Hoogen Raad, dat de taak van inspecteur en accountant dezelfde zou zijn. Hetgeen de Hooge Raad opmerkt omtrent de taak van den inspecteur, als leek op het gebied van contrôle en administratie, kan wellicht als juist worden aanvaard. Maar van den acountant, die geacht moet worden op dit gebied wèl deskundig te $z$ ijn $\longrightarrow$ daarvoor maakt men juist van zijn diensten gebruik - . kan wèl gevorderd worden, dat hij zich onder alle omstandigheden begeeft ,,in het nasporen en waardeeren van alle gegevens, die uit de boekhouding of wel aan de hand daarvan uit andere omstandigheden kunnen worden getrokken." Elke andere opvatting en daarop gegronde beroepsuitoefening leidt op den duur tot een degradatie van het beroep. De accountant, die zich bepaalt tot een beperkt onderzoek in administraties, dat alle mogelijkheid laat, dat de medegedeelde uitkomst niet berust op de befaamde ,goede gronden", doet op den duur geen accountantsarbeid, maar is een detective geworden. I $k$ ben van meening, dat daarmede noch het beroep, nòch de belastingadministratie op den duur is gebaat.

In dit geval was er maar één bevredigende uitspraak mogelijk geweest t.w.:

de accountant had de administratie in vollen omvang behooren te onderzoeken, met name ook of de ontvangsten ten volle in de boekhouding waren verantwoord. Indien de accountant aldus had gehandeld, zou de inspecteur van hetgeen thans als nieuw feit wordt opgeworpen, bij de regeling van den aanslag, op de hoogte zijn geweest. De inspecteur behoorde - nu hij de diensten van een accountant heeft ingeroepen - dat feit ten tijde van de aanslagregeling te kennen, zoodat de navorderingsaanslag ten onrechte is opgelegd.

De overwegingen van de tegengestelde beslissing, welke thans is genomen, hebben helaas de tendenz, het vertrouwen van het publiek in de arbeid van den accountant te ondermijnen.

Het is natuurlijk mogelijk, dat de onjuiste verantwoording van de ontvangsten den accountant zelfs bij de ruimste opvatting van zijn taak, niet kon blijken. Uit het arrest blijkt dit niet. En al zou dit het geval zijn, dan blijft toch de motiveering in het arrest onjuist.

Alhoewel over deze kwestie nog wel meer naar voren zou kunnen worden gebracht, wil ik het thans hierbij laten. Interessant zou het zijn, indien collega's van den Rijksaccountantsdienst, die ongetwijfeld nog een geheel ander licht op de aangeroerde punten zullen kunnen doen schijnen, eveneens hun oordeel daarover in dit blad zouden willen geven.

D. NIJE
NAAR AANLEIDING VAN HET VERSCHIJNEN VAN: Dr O. BAKKER, PRIJSREGELING EN DE THEORIE DER VERVANGINGSWAARDE

Het spreekt vanzelf, dat de ontwikkeling van de bedrijfshuishoudkunde tengevolge heeft, dat in perioden van sterke prijswijzigingen aanleiding wordt gevonden nieuwe formuleeringen te geven omtrent den invloed van prijswijzigingen op kostprijsberekening en winstbepaling. Hoezeer dit op zich zelf te verwachten en omderwille van de ontwikkeling der bedrijfshuishoudkunde te waardeeren is, meen ik eenig bezwaar te moeten maken tegen een publicatie als thans door Dr. Bakker ondernomen. De populaire toon van zijne brochure suggereert den lezer, dat de materie, waarover daarin wordt gehandeld, eenvoudig genoeg is om daarvan een voorstelling te geven, die menigeen zal meenen te kunnen beoordeelen en mogelijk als juist te erkennen. Te sterker spreekt dit, wanneer iemand als Dr. Bakker daartoe overgaat, omdat hij dat dan doet met den inzet van zijn prestige als onderdirecteur van het Centraal Bureau voor de Statistiek.

Ofschoon het niet op mijn weg ligt een polemiek te beginnen voor het forum, waartoe Dr. Bakker zich met zijn brochure gewend heeft, wil ik toch niet gaarne den inhoud van dat werkje in ons vakblad onbesproken laten.

Moge ik dan beginnen met op te merken, dat Dr. Bakker zijn $\S 7$, getiteld "de winstbepaling" begint met de woorden , ik geloof, dat wij bij dit onderwerp aan het cardinale punt gekomen zijn..' Daarmede wordt door hem de verwachting gewekt, dat in die paragraaf dan ook een wijze van winstbepaling zal worden ontwikkeld op grond van een redeneering, waarin met aard en beteekenis van den voorraad in bedrijfshuishoudkundigen zin wordt rekening gehouden. Dit blijkt evenwel in het geheel niet het geval te zijn. Dr. Bakker bepaalt zich tot een toelichting op een tweetal stellingen, betreffende vereischten voor een prijsregeling en gaat in enkele uiterst simpele gevallen de gevolgen na van het door hem voorgestane ten aanzien van een prijsregeling.

Heeft Dr. Bakker de consequentie niet aangedurfd eerst een methode van winstbepaling te verdedigen op basis van de door hem gestelde vereischten voor een prijsregeling om daarna te motiveeren, dat een regeling van de prijzen, behoorende bij zoo'n methode van winstbepaling op den weg van de overheid ligt?

Laat ik eens mogen nagaan tor welke uitspraken Dr. Bakker dan ware gekomen:

,I. In een waardevast geldstelsel is niet de vervangingswaarde, maar de historische kostprijs ... de basis" voor de bepaling van de winst.

Een stelling, die ook vóór 1939 vele malen is gehoord en evenveel malen met succes is bestreden.

De motiveering, door Dr. Bakker gegeven, bestaat uit niets anders dan een enkel voorbeeld, gegeven slechts onder omstandigheden, welke maar één fase van het verschijnsel weergeeft n.l. de prijsstijging. Het luidt n.l. als volgt:

Een handelaar in een bepaald artikel, waarvan hij regelmatig een voorraad van 1000 stuks aanhoudt. Hoewel het geld waardevast is, d.w.z. het prijspeil constant is, is toch de prijs van het hier genoemde handelsartikel gestegen, de vervangingswaarde is grooter dan de historische kostprijs. De laatste zij nu f 1. - per stuk, de normale bruto-winst is $f 0.30$. de vervangingswaarde $f 1,10$ per stuk. Het aantal van 1000 stuks wordt gemiddeld éénmaal per maand omgezet, zoodat de bruto-winst $f$ 300, - per maand is.

Die winst blijft $f 300$, - per maand, ondanks de stijging van den inkoopprijs van $f 1,-$ tot $f 1,10$, wanneer de voorraad 